\title{
INTEGRATING ENVIRONMENTAL AND INTERNATIONAL STRATEGIES IN A WORLD OF REGULATORY TURBULENCE
}

\author{
Frank Wijen \\ Department of Strategic Management and Entrepreneurship \\ Rotterdam School of Management, Erasmus University \\ P.O. Box 1738 \\ 3000 DR Rotterdam \\ The Netherlands \\ E-mail: fwijen@rsm.nl \\ Phone: 31- 10- 4081985 \\ Fax: 31- 10- 4089013

\begin{abstract}
Rob van Tulder
Department of Business Society Management

Rotterdam School of Management, Erasmus University

P.O. Box 1738

3000 DR Rotterdam

The Netherlands

E-mail: rtulder@rsm.nl

Phone: 31- 10- 4081994
\end{abstract}

Fax: 31- 10- 4089019

Published in: California Management Review, 2011, 53(4): 23-46 


\section{SUMMARY}

Companies operating in multiple countries face different and often changing regimes of environmental regulation. This regulatory turbulence raises the question of what environmental strategies multinational enterprises with a portfolio of divergent regulatory regimes should develop in relation to their international business expansion strategies. We argue that multinationals seeking to develop an effective environmental strategy should integrate relative regulatory stringency and international market interdependence. We discuss and illustrate four environmental strategies that match different regulatory/market configurations for multinationals from both developed and emerging markets, as well as the factors that drive strategic changes. We introduce a 'regulatory turbulence tool' that describes relevant regulatory/market configurations and prescribes contingently effective, dynamic environmental strategies. 


\section{INTRODUCTION}

Globalization has left a lasting imprint on the business community. Private and public actors from around the world are increasingly interconnected, materializing through globally disaggregated production value chains, universal consumer products, and non-discriminatory trade regulation. ${ }^{1}$ While economic globalization seems to be undeniable at first sight, a closer look at the international trade and investment statistics suggests that international business is often semi-globalized or regionalized, ${ }^{2}$ thus balancing popular accounts that 'the world is flat'. ${ }^{3}$ Certain markets have remained highly (sub)national in nature. ${ }^{4}$ Besides, internationalization processes include expansion as well as retreat, which may be in response to regulatory fluctuation and changed regulatory differences between a company's home and host countries. So today's international business markets are dynamic and cover the whole spectrum, from global to local.

At the same time, regulatory regimes have predominantly remained the realm of national governments. For sure, the World Trade Organization overrules countries that breach a global level playing field, while the European Union, NAFTA, and Mercosur issue transnational rules that bind countries in a region. ${ }^{5}$ The nation-state remains the main issuer of laws and other regulations in a variety of fields that are relevant to the business community. ${ }^{6}$ Given the national discretion to issue regulation, different political preferences, and uneven government capacities to enforce regulation, ${ }^{7}$ it is obvious that, for a given field, regulatory stringency varies significantly from one country to another. Moreover, regulation does not develop in isolation: countries interact with each other and with corporations, making regulation part of a competitive game. $^{8}$

A prominent example of regulatory regime differences and competition is the natural environment. Certain countries issue stringent regulation that reflects the political desire to protect the natural environment (for its beauty but also for public health reasons), while others 
prioritize economic expansion. ${ }^{9}$ And yet other countries issue stringent regulation but are corrupt or do not have the apparatus to uphold their own rules. ${ }^{10}$ As a result, regulatory regimes pertaining to the natural environment range from very lax to highly stringent. Environmental regulation has recently gained importance, due to (perceived) threats like climate change (e.g., the European emissions trading scheme), ${ }^{11}$ pollution from production epicenters (like eastern China), ${ }^{12}$ and the imminent shortage of strategic natural resources (such as petroleum). ${ }^{13}$ Despite repeated speculations over greater convergence in global environmental regulation due to these developments, regulatory divergence remains considerable. Furthermore, governments regularly change their environmental policies owing to evolving societal preferences. ${ }^{14}$ As a result, firms experience considerable dynamics in their regulatory environments, even if they do not internationalize.

The big question, then, is what forward-looking businesses that operate in multiple countries - which may or may not be interconnected and which may or may not have stringent regulatory regimes - should do. Is it wise for companies to adopt idiosyncratic strategies that meet the specificities of divergent contexts or is it effective to develop regionally or globally uniform strategies? Even more challenging is the question of whether there are strategies that are beneficial to both corporate self-interests and the natural environment. This is a particularly difficult question, since academic studies have shown that socio-environmental efforts do not necessarily lead to higher financial payoffs. ${ }^{15}$ The business case for responsible business is thus not that clear-cut, especially within an international context. On the other hand, it has been argued that companies can reap a sustainable competitive advantage by integrating socio-environmental and economic goals, thereby creating a different 'competitive context'. ${ }^{16}$ Yet, we know little about the implications of different regulatory regimes for the internationalization strategies of multinational enterprises (MNEs). The international business and economics literature has focused on several aspects, 
such as generic strategic approaches for international business,${ }^{17}$ the societal consequences of MNE activities for host countries ${ }^{18}$ the impact of regulatory stringency on international trade and foreign direct investment (FDI), ${ }^{19}$ and the development of 'green' capabilities for MNEs. $^{20}$

While each of these aspects is undeniably relevant, the combination of market interdependence and country specificity has hardly been studied in relation to the natural environment at the firm level. ${ }^{21}$ Especially environmental strategies of MNEs from emerging markets, who have become increasingly important in the global economy, have remained underresearched. Furthermore, most studies have been relatively static, ignoring the changes in regulatory environments to which MNEs are exposed. Our focus, therefore, is on how international businesses should proceed when facing different combinations of market interdependence and regulatory stringency, especially when these forces are dynamic in nature. In particular, what environmental strategies should they adopt that fit particular, evolving interdependence/stringency configurations?

We do so by developing a conceptual framework that draws on both the economic dimension of market interdependence and the institutional dimension of regulatory stringency. We discuss both dimensions and identify strategies that fit particular combinations. Next to articulating the rationale for and form of each environmental strategy, we exemplify the different strategies - drawing on a sample of MNEs originating from both developed and emerging markets - and show the dynamics that may induce MNEs to embrace other strategies. Finally, we elucidate the implications for international business and show how MNEs can implement these strategies in a world of regulatory turbulence. 


\section{INSTITUTIONAL AND ECONOMIC FORCES}

There are specific local and global factors that make up the context within which international businesses operate. For environmental strategies, the regulatory regimes of home and host countries are particularly relevant. It is widely recognized that government regulation is a key institutional determinant of corporate behavior, ${ }^{22}$ especially when pertaining to environmental issues. ${ }^{23}$ Environmental regulation shapes the corporate playing field by limiting or taxing negative environmental effects such as pollution and the use of non-renewable natural resources. ${ }^{24}$ The next important dimension is the economic interdependence of a (prospective) host country's market with those of other countries in which MNEs operate. Economic interdependence affects the strategic discretion subsidiaries have to adjust to the specific conditions of the host countries in which they operate. The international business literature has long studied questions of local versus global corporate strategies, which are driven by the extent to which an MNE's international markets are interrelated. ${ }^{25}$ We extend the discussions of the international business literature, which are typically about generic competitive strategies, to the realm of the natural environment and a measure of regulatory differences.

\section{Regulatory Turbulence}

While environmental regulation can take various forms and cover different topics, its degree of stringency can be considered a key aspect. Stringent regulation is a largely exogenously determined institutional arrangement that covers a variety of aspects (including pollution, natural resource use, and biodiversity) and issues rules that clearly bound and guide corporate behavior. What is more, these strict, comprehensive rules are also enforced. Many countries have environmental regulations that are close to perfection by design, yet of little value because not implemented. ${ }^{26}$ The lack of implementation has a variety of reasons, the most important ones being corruption, shortfalling implementation capacity, and the prioritization of other public policy issues, such as poverty abatement. Unsurprisingly, many 
developing countries have the least stringent environmental regimes. The World Economic Forum (WEF)'s comprehensive assessment of the regulatory stringency of environmental regimes, such as perceived by business executives, shows an enormous variance across countries, ranging from 1.4 for Haiti to 6.7 for Germany (on a 7-point scale). ${ }^{27}$

Over the period 2001-2008, the number of countries increasing their regulatory stringency was approximately matched by the number of those relaxing their environmental regulations. Along this measure, there is no conclusive trend of either regulatory convergence or divergence. Combining different degrees of regulatory stringency and regulatory fluctuation creates distinct country clusters (see Table 1). ${ }^{28}$ Regulatory turbulence captures the combined effects MNEs face due to 'regulatory distance' (measuring differences in the degrees of regulatory stringency of the countries in which MNEs operate) and 'regulatory fluctuation' (indicating changes over time of the regulatory stringency of the countries in which MNEs operate). ${ }^{29}$ Developed countries face, on average, a lower degree of regulatory fluctuation, but are not necessarily exempt from it. Likewise, a number of major developing countries (such as China) show considerable stability - albeit combined with relatively lax regulation. In general, however, countries whose regulatory practices are lenient are also clearly more unpredictable (with a 0.85 correlation between stringency and stability of environmental regulation). ${ }^{30}$

Insert Table 1 approximately here

Lax regulatory regimes are interesting destinations for international business to the extent that they are less bound by strict environmental rules. Companies can use 'outdated' production processes or export products that have been forbidden in more stringent countries because of their adverse effects on the natural environment or public health. While imposing 
fewer restrictions and offering 'pollution havens' for 'dirty' companies, lax regimes also have drawbacks in terms of lower regulatory certainty, as a result of which (foreign) investors may be confronted with overnight changes in official regulation and/or actual practices. Unpredictability tends to discourage (international) business because investments - be they physical or relational - can wear out through such changes. At the macro level, the OECD has calculated that there exists a threshold value of 2.9: FDI decreases when the regulatory distance between home and host countries is too large. Apparently, MNEs perceive foreign investments as (too) risky when the regulatory turbulence they experience is high. The relative regulatory stringency (i.e., the regulatory distance between home and host countries) plays a more important role than the absolute level of regulatory stringency in a (prospective) host country. This finding is comparable to other studies on the relationship between FDI and the influence of regulation (on corruption, governance, and culture). ${ }^{31}$ MNEs thus tend to prefer investing in countries with comparable degrees of stringency. ${ }^{32}$ When companies start internationalizing, it is easier for them to manage their foreign operations in a relatively familiar institutional context. Afterwards, they may move to institutionally more distant host countries. $^{33}$

\section{Market Interdependence}

Next to the institutional context, market forces are an important factor of how international businesses should operate. Since the late 1980s, many production processes have become increasingly internationalized. Quite a few production chains that used to be concentrated in one or a small number of countries - owing to trade-and-investment barriers, high transport costs, and communication difficulties - are now scattered over the globe, giving rise to the notion of 'global factory' and global supply chains. ${ }^{34}$ Exploitation of international factor cost differences (i.e., lowly priced labor, land, or other resources) and the availability of complementary capacities (such as skilled, specialized labor) have led to advanced geographic 
specialization and, hence, a high degree of value chain disaggregation. ${ }^{35}$ While the global factory has enabled international businesses to reduce production bottlenecks and save costs, it has also led to increased interdependence of geographically dispersed markets since the outputs early in the value chain are inputs to subsequent stages located elsewhere. ${ }^{36}$ Growing interdependence goes together with growing vulnerability to disruptions in the system, either through natural causes (such as tsunamis and earthquakes) or man-made drivers (like regulatory upheaval or societal unrest). Regulatory distance turns out to be a much more important factor than cultural distance in the entry-mode decision of MNEs. ${ }^{37}$

Another source of interdependence that many internationally operating companies experience is reputation. This counts especially for firms offering branded consumer products. Companies that manage to 'export' strong corporate or product brands can leverage their reputation. Modern communication technologies have facilitated the international dissemination of corporate or product brands. However, not only companies but also citizens and non-governmental organizations (NGOs) have benefited from the possibilities to reach out to international audiences. As a result, negative or positive events occurring in one country are quickly disseminated around the world. ${ }^{38}$ The old adage that reputation damage travels fast thus has high relevance for firms whose success is contingent on strong reputation and brand image. This is particularly relevant for public business-to-consumer companies, which can instantaneously lose their reputation on markets for capital, consumers, and labor. ${ }^{39}$ Both commercial successes and incidents or failures in one country become immediately exported to other countries, thus constituting another source of market interdependence.

Insert Table 2 about here 
While many international businesses thus face significant market interdependences, this is in no way true for all companies. Many activities have remained local in character owing to their 'strategic nature' (qualifying them for state protection), cultural idiosyncracies (e.g., public relations and media), the continued importance of transport costs (as with soft drinks) or communication costs (as with certain IT applications), the impossibility to internationally trade (such as local services), or the lack of an internationalization tradition (for instance, real estate). An indicator of market interdependence is the Transnationality Index (TNI), which measures the average of the ratios foreign/total assets, sales, and employees for MNEs. A TNI of $50 \%$ or higher indicates that more operations are realized abroad than in an MNE's home country, suggesting a high degree of market interdependence, while a TNI of lower than 50\% indicates a more limited commitment to, and interconnectedness with, foreign operations. ${ }^{40}$

An illustration of uneven propensities to internationalize (and hence to face different degrees of market interdependence) is that MNEs from the United Kingdom internationalize about three times as much as their south-east European counterparts. ${ }^{41}$ The internationalization spread per sector also varies widely. Table 2 represents the TNI per sector for the 100 largest MNEs worldwide and the 100 largest MNEs from developing countries combined, showing a TNI as high as 76.8 for non-metallic mineral products to as low as 36.0 for construction and real estate. ${ }^{42}$ When geographic markets are relatively disconnected, they are either served by local firms or by international companies that have 'gone local'. To recap, geographic specialization as well as corporate and product reputation entail high market interdependence for many internationally operating companies, while firms in certain sectors and from particular home countries tend to have a local orientation. 


\section{ENVIRONMENTAL STRATEGIES}

So far, we have identified two key dimensions that make up the context within which MNEs craft their environmental strategies. The institutional dimension consists of the extent to which the regulatory stringency of a (prospective) host country is low or high relative to an MNE's home country (or portfolio of other countries in which an MNE operates). The economic dimension indicates the degree to which an MNE's operations in a (prospective) host country are interconnected with those in other geographic markets. In this section, we delineate four 'basic' environmental strategies for MNEs entering or operating in a particular host country, based on different combinations of regulatory stringency and market interdependence (see Table 3). ${ }^{43}$

Insert Table 3 about here

To illustrate our argument with 'real-life' examples, we selected four MNEs from developed countries (with relatively stringent regulations in their home countries) and four MNEs from major emerging markets (with relatively lax home regimes). The selected MNEs operate in sectors such as oil and gas, chemicals, electronics, and construction materials industries which are prime targets for environmental regulation. We followed these companies over the period 2001-2008, during which they followed different internationalization paths - thereby facing considerable international regulatory distance and fluctuation. The selected MNEs in the oil-and-gas sector are CNPC (China), Petrobras (Brazil), and Shell (United Kingdom-Netherlands). The chemicals sector is represented by Sinochem (China). Acer (Taiwan) and Philips (Netherlands) are electronics companies. The construction industry includes CEMEX (Mexico) and Tata Steel (India). 
For each case company, we selected the five key host countries, based on either their largest sales markets and their biggest production and exploration sites. Table 4 presents for each MNE the TNI and the most important markets (home country and five main host countries) over the period 2001-2008. The table also describes the regulatory stringency and fluctuation per country as well as the difference between the laxest regime and the strictest one ('regulatory spread') and the discrepancy between the least stable regime and the most stable one ('fluctuation amplitude'). All MNEs faced considerable regulatory spread and fluctuation. CEMEX, Tata, and Sinochem are the companies with the lowest spread of stringency degrees. The companies with the highest coordination problems due to very high regulatory turbulence are Shell, CNPC, and Petrobras, which had to invest in regulatorily weak and/or unstable countries (like Nigeria, Angola, and Sudan). Acer and Philips also experienced considerable regulatory dissimilarities due to the importance of both developed and developing countries in their market portfolios. Most companies thus faced the challenge of coping with high regulatory distance and strong fluctuation.

Insert Table 4 about here

\section{Strategy 1: Fictitious Forcing}

When regulatory regimes are relatively lax and international interdependences are relatively low, firms face few restrictions and enjoy much discretion to operate as they deem fit. Under such circumstances, it is tempting for firms to engage in a 'race to the bottom' by having recourse to 'dirty' processes and products, since such behavior is neither sanctioned by regulatory authorities nor by international markets. Leading MNEs from emerging markets (such as CNPC, Petrobras, Sinochem, and Tata Steel) initially did so in their home markets, 
since they were operating in rather weak regulatory regimes and were relatively protected from foreign competition.

Withstanding the temptation to adopt environmentally adverse practices is a wise strategy for forward-looking MNEs, for three reasons. First, the least stringent regulatory regimes also tend to be the most unpredictable ones. High tolerance of business activities with adverse environmental consequences may quite abruptly be followed by great zeal to uphold environmental values. Companies which may be tolerated under lax regimes but which live on a wrong footing with their local environments, thus having low legitimacy among the local population and authorities, become an easy target of radical changes - for instance, following popular upheaval after ecological incidents involving casualties. ${ }^{44}$ Indeed, proactive environmental strategies are rewarding for MNEs in the face of such regulatory uncertainty. ${ }^{45}$ Voluntary corporate action is a particularly rational option to the extent that environmental investment costs are typically low and thus do not undermine corporate competitive positions, ${ }^{46}$ whereas the societal payoff due to precluded conflicts can be significant. ${ }^{47}$

A second reason for not lowering the bar is that abundant natural resource use and pollution can be considered forms of economic inefficiency. ${ }^{48}$ Production processes requiring intensive energy use, ample raw materials, or emitting residual substances are manifestations of suboptimality. According to this philosophy, more (economic output) can be achieved with less (environmental load) by having a close look at how to use resources in more effective and efficient ways. ${ }^{49}$ Technological innovations that reduce negative environmental effects (e.g., by reducing natural resource consumption) may also grant companies a competitive edge. ${ }^{50}$

A third reason to do more than required is to comply with commitments in stringent regimes through actions in countries with laxer regulations. For climate change, a global environmental problem, flexible instruments such as Joint Implementation and Clean Development Mechanism are in place, which allow firms to meet their emission-reduction 
targets through relatively low investments in countries with more lenient regimes. For instance, the European Union limits greenhouse gas emissions of oil-and-gas companies, who may find it more cost-effective to obtain emission credits through voluntary investments in emerging markets. $^{51}$

While there are thus good business reasons to adopt environmentally stringent practices in relatively autonomous markets with lenient regulatory regimes, companies are unlikely to do so on a voluntary basis or at a sufficient pace. Therefore, they need to embrace a strategy of 'fictitious forcing': acting as if they were forced by a stringent regulatory regime to operate with a low environmental impact. Necessity is the mother of all innovation. Without the perceived necessity to change, companies tend to stick to their 'business-as-usual' routines, ${ }^{52}$ especially in very competitive markets that stress short-term results, ${ }^{53}$ thereby foregoing opportunities to cut costs through eco-efficiency measures and tap into new sales markets for environmentally sensitive customers. ${ }^{54}$ Challenging these routines implies imagining very stringent future regulation around core environmental issues and then 'backcasting' solutions to implement this fictitious regulation. ${ }^{55}$ In case this regime materializes later on, companies have taken a headstart. In case it does not, they can still benefit from certain business advantages such as cost savings, extra revenues, and boosted employee motivation. ${ }^{56}$ It should also be kept in mind that small investments can have substantial environmental payoffs (such as purifying effluent water to save the local environment), thereby enhancing the local legitimacy of corporate activities.

This strategy thus looks like a 'no regret' option but goes beyond easy, low-hanging-fruit measures by self-questioning existing activities. This is not to say that environmentally benign initiatives always pay off, but many companies leave an existing potential underutilized or even untapped. For instance, Tata, which in its early internationalization process entered host countries with relatively lenient regimes, has a strong track record of corporate responsibility, 
among other reasons out of enlightened self-interest. Tata Motors recently launched the Nano car, designed for emerging markets (with their lenient regimes) but meeting stringent (European Union) norms for vehicle emissions. ${ }^{57}$ Petrobras has also adopted a beyondcompliance environmental strategy. Alarmed by several oil spills in its home country in the early 2000s, the MNE forced itself into a rigorous spill-prevention program (including a formal environmental management system and a proactive culture), drove its suppliers to become greener, and entered into renewable energy. ${ }^{58}$ An example of a fictitious forcing strategy by an MNE from a developed country is Philips' woodstove, an innovative product designed specifically for low-income consumers in developing countries, reducing wood consumption and abating in-door air pollution that ensue from open-fire cooking. ${ }^{59}$

Implementing a fictitious forcing strategy starts by identifying the main environmental challenges. For natural-resource-intensive MNEs, this may be deforestation (for instance, to grow palm trees) and shrinking biodiversity (due to monoculture). Manufacturing firms may see air pollution and energy efficiency as key environmental challenges, while service companies may face energy consumption and greenhouse gas emissions from transport movements as the main issues. Once identified, MNEs then address the main environmental challenges through the adoption of existing 'best practices' - such as those implemented by firms operating in environmentally stringent regimes - or, in their absence, by thinking up measures that would be likely candidates for combating undesired environmental effects. Next, MNEs assess how such measures would impact existing or prospective business operations. The final step is to take organizational and technical initiatives that both make business sense (by using fewer inputs, serving environmentally sensitive markets, etc.) and that lead to conformity with the fictitious stringent regime. In short, MNEs facing few institutional and market restrictions should still imagine very stringent regulation around their 
core environmental issues and adopt profitable measures to comply with such a fictitious regime.

\section{Strategy 2: Local Compliance}

A persistent misconception is that international firms expand their activities from countries with stringent environmental regulation to those with laxer regimes. Yet, in many cases, companies have operations in foreign countries with more stringent regulatory regimes. Many FDIs are among developed countries - including those from countries with relatively lenient regimes to those with stricter regulations - because of the need of complementary, skilled labor. ${ }^{60}$ While emerging-market MNEs such as CNPC and Petrobras tend to favor investments in nearby countries or regions with relatively weak regulatory regimes, they are increasingly entering developed countries as well. ${ }^{61}$ Such investments require these emerging-market MNEs to overcome considerable upward regulatory distance - although they also benefit from the reduced regulatory fluctuation that typifies more demanding regimes. When MNEs are confronted with more stringent host-country environmental regulation and when their activities have little interdependence with operations in other countries, the best strategic choice is to comply with local regulation. First because MNEs have but little choice: companies that fail to comply with environmental regulations that are enforced - as is the case in stringent regimes - will be sued, thereby compromising their business continuity. Second, there is no reason to defect because their competitors are exposed to the same strict rules, thus ensuring a level playing field that does not leave them worse off when complying.

Implementing a local compliance strategy is relatively straightforward, since the regulatory authorities will impose meeting a number of environmental stipulations (in relation to air, water, and land pollution, energy efficiency, and ban of toxic substances), typically specified in environmental permits, as a prerequisite for getting a license to operate. Meeting these regulatory demands implies that firms need to obtain new knowledge, to the extent that 
compliance may necessitate unprecedented changes of practices. The adoption of more advanced environmental practices may involve investing in more state-of-the-art technologies, changes of components or other product specifications, and reconsidering extant corporate routines. Such changes are often challenging, since MNEs are inclined to transfer home-country practices to host countries. 'Going local' or relying on externally obtained or co-developed competencies through acquisitions or joint ventures in other host countries with stringent regimes may then be imperative to comply with local regulatory requirements.

Joint ventures and acquisitions are, indeed, effective ways of coping with the regulatory differences between home and host countries, because they enable MNEs to bridge the competency gap that results from facing a relatively stringent host-country regime - even though such entry modes entail higher coordination costs. The recent generation of emergingmarket MNEs (such as Tata Steel and Sinochem) have used such 'springboarding' strategies to enter developed countries, ${ }^{62}$ often at prices well beyond book value, to acquire advanced technological and organizational knowledge, including environmentally relevant know-how. ${ }^{63}$

\section{Strategy 3: Standard Extension}

Even when regulatory pressure is low, an MNE has only little discretion when corporate activities in a host country are interconnected with those elsewhere. First, disaggregated value chains rely on product or process standards as a way to integrate the activities performed at geographically dispersed locations. ${ }^{64}$ Firms with operations in different countries require their subsidiaries or external suppliers to scrupulously comply with carefully designed standards to ensure the different components or sequences of actions are compatible. Another reason to standardize is to achieve economies of scale (i.e., low costs of components procured in bulk quantities or declining production costs from cumulative learning-by-doing). ${ }^{65}$ When standardized products are designed, the environmental standards of the most stringent regulatory regime become determinant. ${ }^{66}$ Failing to comply precludes companies from serving 
the market with stringent environmental regulation, while beyond-compliance never leads to exclusion. Therefore, firms applying advanced standards in the home market (or other host countries) to meet home-market (or other host-country) regulatory requirements should extend these standards to host countries with more lenient regimes. For instance, airplanes that cannot exceed certain noise or emission levels to enter North American airports will also be produced for African customers who only perform intracontinental flights, since aircraft are highly standardized products. International firms whose corporate or brand reputation is a distinctive competitive advantage (like Philips or CEMEX, both having high degrees of transnationality) extend home-country standards to host countries with lax regimes for a different reason. Environmentally unfriendly processes or products by highly visible firms as is the case with companies thriving on their reputation - are easy targets of environmental activists. ${ }^{67}$ They will readily identify and communicate 'environmental evils' to the outside world, arguing that these powerful companies take advantage of vulnerable host countries. Since modern communication technologies bring such information almost instantaneously to citizen-consumers around the world, adversely perceived practices are a threat to companies with internationally known names. Therefore, companies seeking to safeguard their reputation have every reason to shy away from inferior environmental practices. Oftentimes, MNEs from developed countries scrupulously comply with local legislation in weak regimes to avoid negative publicity in their home countries. ${ }^{68}$ Oil-and-gas company Shell failed to do so and suffered substantial reputation damage in a series of alleged environmental offenses, including oil spills in Nigeria. The company was recently removed from the Dow Jones Sustainability Index of leading companies. ${ }^{69}$ By contrast, Philips - which has outsourced most of its production activities - has imposed relatively stringent environmental standards on all of its suppliers, including those from countries with lenient regimes. 
A related motive for using environmental practices beyond local institutional requirements is to signal to environmentally sensitive customers that the natural environment has been respected despite a regulatory void at the location of production. Indeed, ecolabels have mushroomed over the past few years, showing customers in (generally wealthy) export markets that the products were produced under environmentally responsible conditions. ${ }^{70}$ Ecolabels are voluntary standards seeking to regulate environmental aspects of economic activities, including - or even especially - in countries with lax regimes. Companies adopt ecolabels as a 'satisfier' for customers that only buy 'responsible products' or as a mark-up for customers willing to pay a price premium for preserving the environment. The DutchBritish food MNE Unilever attaches much importance to globally uniform environmental standards and has played a leading role in the development and implementation of the Marine Stewardship Council label for sustainable fishing. ${ }^{71}$ Ecolabels differ from corporate or brand reputation in the sense that these labels are not company-specific - as such 'proprietary' labels would undermine their credibility - and focus on environmental characteristics as such, whereas reputation generally pertains to product quality and image. Yet both concur in the sense that they aim to communicate tenets that are not embodied in the products and are thus not observable by (lay) customers, such as the impact on the natural environment or public health. ${ }^{72}$ In a similar vein, many MNEs have imposed ISO 14001 certification for all of their subsidiaries to signal their commitment to systematic environmental management to the outside world. ${ }^{73}$

Implementing a standard extension strategy starts by identifying those aspects of local operations that have repercussions for business activities in other countries. These may be components that are banned in export markets, standardized semimanufactures to be assembled with elements produced in another country, reputational exposure because of the presence of foreign NGO watchdogs, etc. In the case of standards, the next step is to apply the 
product specifications that have been designed up front or to prescribe process and output criteria to comply with ecolabel requirements. When there is reputational risk, standard operating procedures need to be put in place to minimize the likelihood of environmental incidents. Furthermore, companies should avoid practices that are likely to attract negative attention from NGOs (such as the use of chemicals outlawed elsewhere). Given the regulatory vacuum, corporate enforcement or third-party control are critical to ensure that rules are abided by. ${ }^{74}$ In sum, international business should extend relatively stringent standards to more lenient host countries when their business models thrive on standardized products and processes, corporate or product reputation, and responding to environmental customer demands.

\section{Strategy 4: Standard Upgrading}

A different strategy is called for when markets are interconnected yet the (prospective) host-country regulatory regime is more stringent than the ones encountered in other countries in which MNEs operate. In order to access a new market with more stringent environmental requirements than those in existing markets, MNEs need to adjust to the most stringent regime (i.e., the new host country). Like before, this ratcheting up is important when companies have standardized processes and products to reap scale economies, thrive on corporate or brand reputation to serve upper-echelon markets, and/or serve environmentally conscious customers.

Standards meeting regulatory requirements, societal expectations, and customer demands in a host country with an environmental regime that is stringent relative to those experienced elsewhere then set the stage for company-wide practices. As a result, MNEs need to upgrade existing standards to the level of the most stringent host-country regime. Obviously, entering a relatively demanding host country is only attractive for MNEs to the extent that the costs of switching to the higher host-country standards are outweighed by advantages such as getting access to financially rewarding or strategically significant production locations and sales 
markets. Given the necessity to perform company-wide changes, this strategy differs fundamentally from the previous strategy, which entails merely extending existing standards to another country. An illustration of a standard upgrading strategy is Acer, which put a lot of effort into establishing a strong global brand name - thereby becoming more transnational. One way of improving its reputation in major sales markets such as the United States and Europe has been to upgrade its environmental standards, which Greenpeace rated at 2.3 in 2005 and 4.1 in $2010 .^{75}$

Implementing a standard upgrading strategy entails first identifying those regulatory stipulations that have relevance for operations in other countries. The next step is to assess which operations or outputs would lead to mismatches with operations or outputs in other countries. Rectifying these mismatches will then lead to redesigning product specifications or banning certain substances used elsewhere. Host countries need to be attractive locations (in terms of production or sales markets) before companies universally adjust their existing standards to accommodate the regulatory demands in more stringent regimes. California and Germany are examples of large markets with relatively stringent regulatory regimes that have induced several MNEs to upgrade their standards. ${ }^{76}$

\section{Environmental Strategy Dynamics}

Regime changes can lead to both stricter and laxer regulations. Furthermore, interdependences among an MNE's geographic markets may increase or decrease over time. As a result, four types of dynamics can be elaborated (see Table 5).

Tightening up. Affluent nation-states tend to have more stringent environmental regimes than poorer countries. ${ }^{77}$ Therefore, lax regimes are likely to become stricter when countries become more prosperous. This happens because higher national income gives authorities more tax income and hence more latitude to combat corruption and enhance regulatory enforcement capacity. ${ }^{78}$ Another reason is that, once basic needs have been met, people attach 
more priority to environmental protection and will pressurize their politicians to issue and enforce stringent regulation. ${ }^{79}$ So, over time, a country's regulatory regime tends to tighten up when national income rises. An example of a (recently) changing regulatory regime is China, where the enormous environmental challenges and enhanced prosperity have driven the authorities to become less tolerant of industrial pollution, partly in response to popular protests against heavily polluted living areas. ${ }^{80}$ Companies with a fictitious forcing strategy obviously have a headstart vis-à-vis less forward-looking firms when a regulatory regime tightens up. MNEs with high market interdependence may have to change from extending to upgrading their standards. For instance, when CNPC's international branch (Petrochina) became listed on the New York Stock exchange in 2000, it embraced international (environmental) standards; in 2010, it also adopted a new 'green' logo.

Loosening up. While regime tightening is the more frequent type of change, given rising incomes and magnifying environmental problems (especially in emerging markets), regulatory regimes may also loosen up. This can happen when newly elected politicians form governments that attach less importance to environmental preservation. Alternatively, governments may relax environmental policies to attract foreign investors. While there is no strong evidence of a 'race to the bottom', certain pollution-intensive industries (such as basic metals, chemicals, and paper-and-pulp) are sensitive to such changes given the relatively high costs of complying with stringent regulation. ${ }^{81}$ In such cases, forward-looking MNEs are still better off pursuing a (business) win - (environmental) win through a fictitious forcing strategy or fall back on their global/home-country standards. For instance, while the United States has still not adopted a stringent greenhouse-gas-reduction policy at the federal level, many companies have taken proactive mitigation measures, both to anticipate potential future regulatory changes and to benefit from the associated economic benefits, especially in terms of resource efficiency. ${ }^{82}$ The degree of regulatory fluctuation in the home market also plays a 
role in this strategy. An MNE like Shell faced more regulatory turbulence in its Dutch home country than, say, German-based MNEs. Such fluctuations might stimulate the company to lower the performance level of its environmental practices, both at home and in its host countries.

Insert Table 5 about here

Coupling. Another dynamic is that MNEs may turn their local strategies into more global ones. Fictitious forcing or the necessity to comply with local legislation may induce companies to come up with solutions that eventually bring them competitive advantage, thereby driving firms to turn local successes into more global standards. An example is Philips, which initially had a reactive compliance strategy to meet the environmental requirements of Dutch authorities. While doing so, the firm discovered the business opportunities of eco-efficiency and positioning products as 'green flagships', which have now become part of Philips' global strategy to save costs and boost its reputation as an environmentally responsible company.

Decoupling. An opposite dynamic may also unfold. When the costs of adjusting existing standards to the requirements of stringent host countries outweigh the advantages or if regulatory requirements strongly diverge across countries, companies may choose to 'decouple' market interdependencies. For instance, the very stringent REACH legislation (around the registration, evaluation, and authorization of chemical substances) in the European Union might drive a company like Sinochem to decouple its costly European environmental practices from those in its home country (China) to avoid such high costs in the latter market. Decoupling can be done by designing and producing different products and by using different brands for host countries with stringent regimes. In such cases, the foregone 
scale economies and/or reputational benefits are smaller than the costs of global adjustments to standards or brands. Decoupling puts MNEs back into the traditional position of a multidomestic organization. Since most companies either face or anticipate increasing degrees of internationalization and market interdependence, this strategic change is relatively unattractive.

\section{CONCLUSION: MANAGING REGULATORY TURBULENCE}

We have shed a light on effective environmental strategies for MNEs against the backdrop of regulatory regimes that diverge across countries and show varying degrees of fluctuation. Given these international differences, companies struggle with the question of whether to 'go local' and adjust to the prevailing regulatory regimes in host countries or to adopt globally or regionally uniform standards, and, if so, which ones. Our main argument is that the appropriate environmental strategy is not a one-size-fits-all answer but is contingent on both the regulatory regime of a host country and the degree to which a company's international markets are interconnected. We have thus argued that environmental strategies of MNEs are most effective when aligned with their internationalization strategies.

We introduced a regulatory turbulence tool, consisting of a two-sponged approach. First, the descriptive component (presented in Table 4) assesses the market interdependence of MNEs (as measured through their TNI score) in conjunction with the regulatory stringency and changes over time of the environmental regulations of their major production and sales countries (based on the WEF's ranking of national regimes). Second, the prescriptive component (summarized in Table 5) indicates which strategies are most effective for MNEs given their market/regulation combinations and dynamics.

By taking an integrative view, we have explored under what conditions environmentally benign actions make business sense. When environmental considerations are core ingredients 
of a company's business strategy, the environmental function is much better secured than when the environment is regarded in isolation and only costs money to meet regulations. ${ }^{83}$ Integrative decisions based on a holistic view of MNE activities thus offer opportunities to see the natural environment as a source of cost savings and additional revenues. While the business advantages of environmentally proactive strategies have been recognized earlier, they have hardly been analyzed in the context of MNEs facing a world of regulatory turbulence - and even less so for MNEs from emerging markets. Central to our argument is that environmental strategies should not only take into account (prospective) host-country regulatory regimes but also a company's interactions with operations in other countries. Since MNEs are faced with different degrees of regulatory stringency and market interdependence, their strategies are only effective when tailored to the relevant combination of these institutional and economic factors.

Environmental strategies are not static. Regulatory regimes not only differ across countries but are also in flux. Economic affluence or crisis, environmental incidents, and political elections impact the evolution of the stringency of environmental regulations. As a result, international businesses may need to reconsider their environmental strategies when such regime changes occur, since laxer or stricter regimes call for different strategies. While regulatory regimes are largely exogenously determined (i.e., outside of the sphere of influence of most MNEs), the degree of market interdependence is more endogenous to international businesses. Firms can decide to leverage successful local business practices by turning them into corporate standards for other countries. Alternatively, when the costs of local compliance are high or reputational risks are present, they may deliberately forego scale economies and decouple their environmental practices.

We have argued that there are ample opportunities to reconcile environmental and business strategies, but also recognize that the 'holy grail' of 'doing well by doing good' has its 
limitations. Certain environmentally benign actions pay off financially, while others do not because their effects are external to the companies taking them. There is often, but not always, a business case for proactive environmental strategies. While disregarding the natural environment or setting low environmental ambition levels may be tempting when operating in countries with lax regimes, we have argued that this may backfire on MNEs - both locally (by foregoing business opportunities or encountering clashes with local communities) and globally (by suffering from mismatches with business operations in other countries). When there is no pecuniary payoff, MNEs should either merely comply with prevailing rules or invoke the 'normative case' for environmentally benign actions. ${ }^{84}$ The latter might be especially relevant in lax regimes with 'regulatory voids.' Since many positive environmental outcomes take modest financial investments, companies do not have to compromise their competitive positions when taking relatively advanced environmental measures, even when not required by law. Using this strategic discretion and integrating contextualized, dynamic regulatory and market imperatives are the foundations for crafting realistic and sustainable environmental strategies. 
Table 1: Regulatory Stringency/Fluctuation Combinations in Selected Countries (2001-2008)

\begin{tabular}{|c|c|c|c|c|}
\hline & & \multicolumn{3}{|c|}{ Average Environmental Regulatory stringency } \\
\hline & & Low & Medium & High \\
\hline \multirow[t]{3}{*}{$\begin{array}{l}\text { Regulatory } \\
\text { Fluctuation }\end{array}$} & Low & $\begin{array}{l}\text { Argentina; China; } \\
\text { Ecuador; Philippines; } \\
\text { Russia; Zimbabwe }\end{array}$ & $\begin{array}{l}\text { Estonia; Latvia; Mexico; } \\
\text { Poland; Portugal; Spain; } \\
\text { Thailand }\end{array}$ & $\begin{array}{l}\text { Australia; Belgium; } \\
\text { Canada; Denmark; } \\
\text { Finland; Germany; Japan; } \\
\text { New Zealand; Norway; } \\
\text { Singapore; Sweden; } \\
\text { Switzerland; Taiwan; } \\
\text { United Kingdom }\end{array}$ \\
\hline & Medium & $\begin{array}{l}\text { Bolivia; Guatemala; } \\
\text { Honduras; Nicaragua; } \\
\text { Peru; Sri Lanka; Ukraine; } \\
\text { Venezuela }\end{array}$ & $\begin{array}{l}\text { Bulgaria; Chili; } \\
\text { Colombia; Costa Rica; } \\
\text { Greece; Hong Kong; } \\
\text { Hungary; South Korea; } \\
\text { South Africa; Lithuania }\end{array}$ & $\begin{array}{l}\text { Austria; Czech Republic; } \\
\text { France; Ireland; } \\
\text { Netherlands; United } \\
\text { States }\end{array}$ \\
\hline & High & $\begin{array}{l}\text { Angola; Bangladesh; } \\
\text { Indonesia; Morocco; } \\
\text { Nigeria; Pakistan; } \\
\text { Vietnam }\end{array}$ & $\begin{array}{l}\text { Brazil; Egypt; India; } \\
\text { Israel; Italy; Malaysia; } \\
\text { Turkey }\end{array}$ & Iceland; Ireland \\
\hline \multicolumn{5}{|c|}{ Stringency: low $=1.4-3.4 ;$ medium $=3.5-4.9 ;$ high $=5.0-6.7$} \\
\hline \multicolumn{5}{|c|}{ Fluctuation: low $=0.0-0.2 ;$ medium $=0.3-0.4 ;$ high $=0.5-1.0$} \\
\hline
\end{tabular}


Table 2: Sectoral Transnationality Index

\begin{tabular}{|c|c|c|}
\hline Sector & $\begin{array}{l}\text { Number of } \\
\text { 'Top 100' } \\
\text { MNEs }\end{array}$ & $\begin{array}{l}\text { Average TNI per } \\
\text { sector }\end{array}$ \\
\hline Non-metallic mineral products & 5 & 76.8 \\
\hline Industrial Services & 4 & 73.5 \\
\hline Aircraft & 3 & 68.7 \\
\hline Food, beverages, and tobacco & 11 & 63.7 \\
\hline Diversified & 14 & 63.4 \\
\hline Pharmaceuticals & 10 & 63.3 \\
\hline Transport and storage & 5 & 61.3 \\
\hline Chemicals & 5 & 60.3 \\
\hline Other consumer services & 5 & 59.8 \\
\hline Other consumer goods & 5 & 57.9 \\
\hline $\begin{array}{l}\text { Electrical \& electronic } \\
\text { equipment }\end{array}$ & 23 & 57.0 \\
\hline Motor vehicles & 12 & 56.8 \\
\hline Mining \& quarrying & 6 & 56.2 \\
\hline Telecommunications & 18 & 55.9 \\
\hline $\begin{array}{l}\text { Utilities (Electricity, gas, and } \\
\text { water) }\end{array}$ & 13 & 54.6 \\
\hline Retail \& Trade & 4 & 53.9 \\
\hline Wholesale trade & 7 & 53.6 \\
\hline Wood and paper products & 1 & 53.6 \\
\hline Other equipments goods & 3 & 53.0 \\
\hline Metal and metal products & 14 & 47.7 \\
\hline Petroleum expl./ref./distr. & 19 & 43.3 \\
\hline Construction and real estate & 7 & 36.0 \\
\hline
\end{tabular}


Table 3: Environmental Strategies for Regulation/Market Configurations

\begin{tabular}{|c|c|c|c|}
\hline & & \multicolumn{2}{|c|}{ Regulatory Regime: Degree of Host-Country Stringency } \\
\hline & & Low & High \\
\hline $\begin{array}{l}\text { Market } \\
\text { Interdependence: }\end{array}$ & Low & Fictitious Forcing Strategy & Local Compliance Strategy \\
\hline $\begin{array}{l}\text { Degree of } \\
\text { Transnationality }\end{array}$ & High & Standard Extension Strategy & Standard Upgrading Strategy \\
\hline
\end{tabular}


Table 4: Regulatory Turbulence Portfolio for Selected Cases

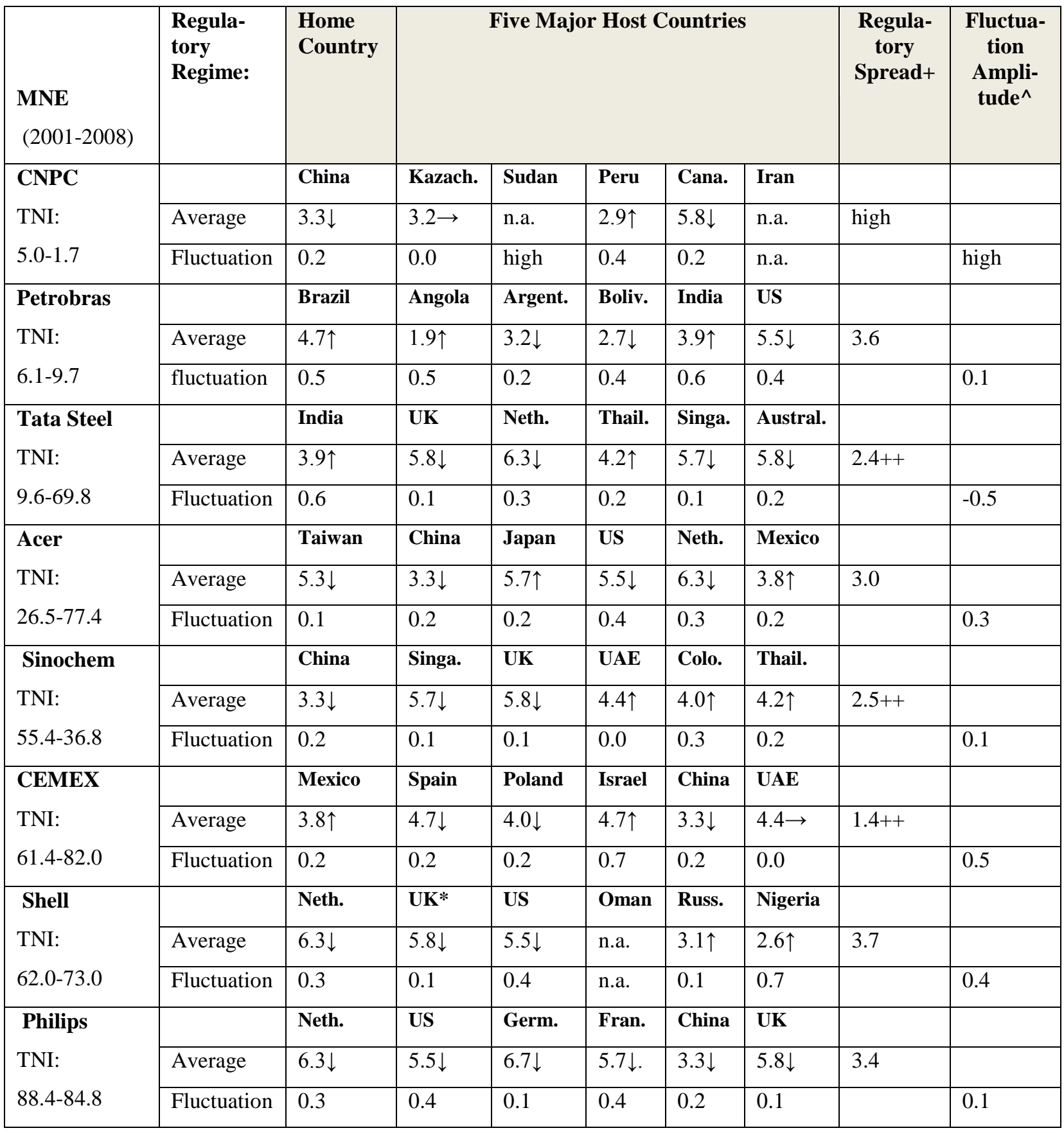

* Dual home country

+ Regulatory spread: maximum distance between highest and lowest regulatory regime

++ Score is below the regulatory 'threshold' value of 2.9

$\wedge$ Fluctuation amplitude: highest distance above home-country level of fluctuation

$\uparrow \downarrow$ Direction of change in the 2001-2008 period 
Table 5: Environmental Strategy Dynamics for Regulation/Market Configurations

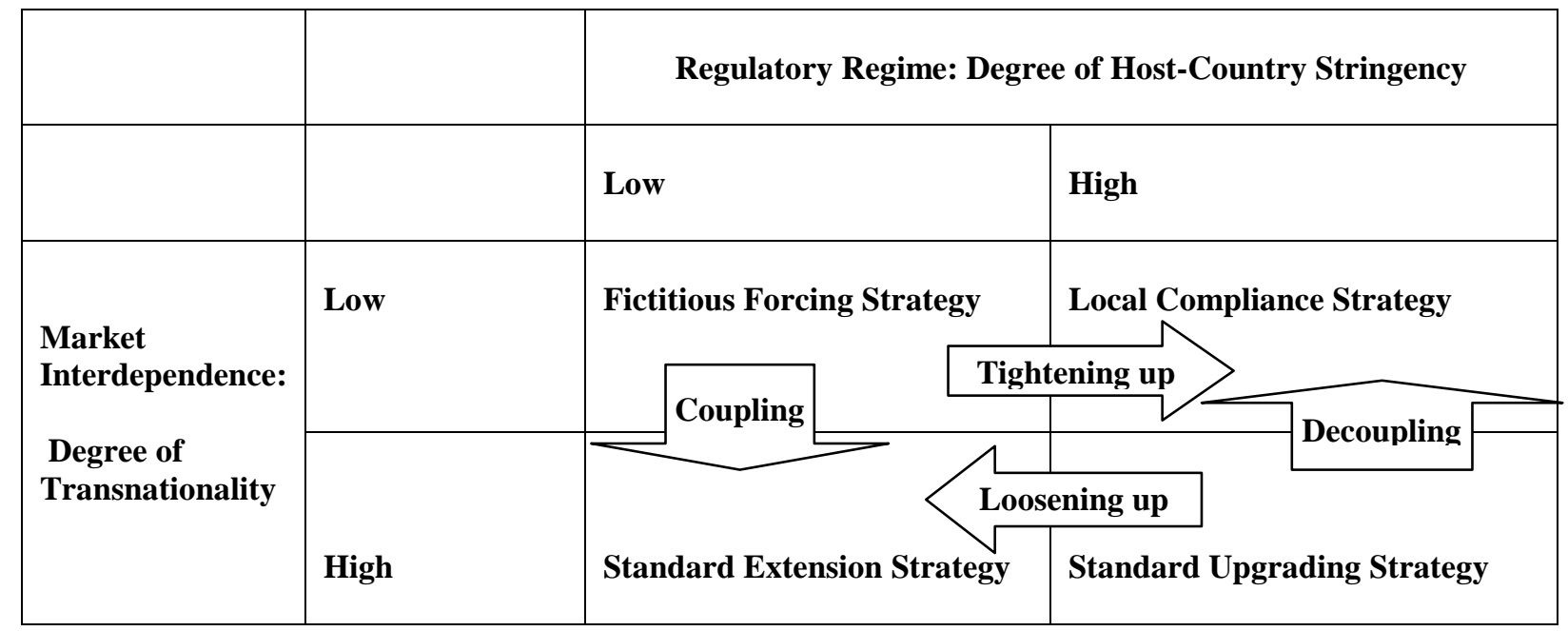




\section{Notes}

1J. Dunning, Global capitalism, FDI and Competitiveness: The Selected Essays of John H. Dunning, Volume
II (Cheltenham: Edward Elgar, 2002); M. Castells, The Rise of the Network Society; The Information Age:
Economy, Society and Culture, Volume 1 (Massachusetts: Blackwell, 1996); D. Hummels, "Transportation costs
and international trade in the second era of globalization," Journal of Economic Perspectives, 21/3 (2007): 131-
154; B. Parker, Globalization and Business Practice: Managing across Boundaries (London: Sage, 1998).
2 P. Ghemawat, "Semiglobalization and international business strategy," Journal of International Business
Studies, 34/2 (2003): 138-152; A. Rugman, The End of Globalization (London: Random House, 2000).
${ }^{3}$ T. Friedman, The World is Flat: A Brief History of the Twenty-First Century (New York: Farrar, Straus, and
Giroux, 2005).
4 P. Ghemawat and F. Ghadar, "Global integration $\neq$ global concentration," Industrial and Corporate Change, 15/4 (2006): 595-623; UNCTAD/Erasmus University, World Investment Report 2010: Investing in a Low Carbon Economy (New York: United Nations, 2010).

${ }^{5}$ J. Braithwaite and P. Drahos, Global Business Regulation (Cambridge: Cambridge University Press, 2000).

${ }^{6}$ D.J. Frank, A. Hironaka, and E. Schofer, "The nation-state and the natural environment over the twentieth century," American Sociological Review, 65(February 2000): 96-116.; J. Verschuuren, "Overcoming the limitations of environmental law in a globalised world," in F. Wijen, K. Zoeteman, J. Pieters, and P. van Seters (eds.), A Handbook of Globalisation and Environmental Policy: National Policy Interventions in a Global Arena, $2^{\text {nd }}$ ed. (Cheltenham: Edward Elgar, 2011).

${ }^{7}$ D. Kaufmann, A. Kraay, and M. Mastruzzi, "Governance matters IV: Governance indicators for 19962004," http://info.worldbank.org/governance/wgi2007/, (Washington, D.C.: World Bank, 2005).

${ }^{8}$ J. Braithwaite and P. Drahos, Global Business Regulation (Cambridge: Cambridge University Press, 2000); C. Oliver and I. Holzinger, "The effectiveness of strategic regulatory management: A dynamic capabilities framework," Academy of Management Review, 33/2 (2008): 496-520.

${ }^{9}$ M. Kalamova and N. Johnstone, "Environmental policy stringency and foreign direct investment," in F. Wijen et al. (eds.), op. cit.

${ }^{10}$ Kaufmann et al., op. cit.

11 Engels, A. 2006. "Market creation and transnational rule-making: The case of $\mathrm{CO}_{2}$ emission trading," in M.-L. Djelic and K. Sahlin-Anderson (Eds.), Transnational Government: Institutional Dynamics of Regulation (Cambridge: Cambridge University Press).

${ }^{12}$ World Bank, The Cost of Pollution in China: Economic Estimates of Physical Damage (Washington, D.C.: World Bank, 2007).

${ }^{13}$ The Times, "Shell chief fears oil shortage in seven years," 25 January 2008; The Guardian, "US military warns oil output may dip causing massive shortages by 2015," 11 April 2010.

14 P. Rivoli and S. Waddock, "“First they ignore you...": The time-context dynamic and corporate responsibility," California Management Review, 53/2 (Winter 2011): 87-104.

15 D. Vogel, The Market for Virtue: The Potential and Limits of Corporate Social Responsibility (Washington, D.C.: Brookings Institution Press, 2005); T. Hahn, F. Figge, J. Pinkse, and L. Preuss, "Editorial: trade-offs in corporate sustainability: you can't have your cake and eat it," Business Strategy and the Environment, 19/4 (2010): 217-229; J.A. Aragón-Correa and E. Rubio-López, "Proactive corporate environmental strategies: Myths and misunderstandings," Long Range Planning, $40 / 3$ (2007): 357-381.; J. Margolis and J. Walsh, "Misery loves company: Rethinking social initiatives by business," Administrative Science Quarterly 48/2 (2003): 268-305.

${ }^{16}$ M. Porter and M. Kramer, "The competitive advantage of corporate philanthropy," Harvard Business Review, 80/12 (December 2002): 56-68; M. Porter and M. Kramer, "Creating shared value: How to reinvent capitalism - and unleash a wave of innovation and growth," Harvard Business Review, 89/1-2 (January-February 2011): 63-77; F. Reinhardt, "Bringing the environment down to earth," Harvard Business Review, 77/4 (JulyAugust 1999): 149-157.

${ }^{17}$ J. Dunning, Multinational enterprises and the global economy (Wokingham: Addison-Wesley, 1993); C. Bartlett and S. Ghoshal, Managing across borders: The transnational solution (Boston: Harvard Business School Press, 1989); C. Prahalad and Y. Doz, The Multinational Mission: Balancing Local Demand and Global Vision (New York: Free Press, 1987).

18 P. Buckley and P. Ghauri, "Globalisation, economic geography and the strategy of multinational enterprises," Journal of International Business Studies, 35/2 (2004): 81-98; IMF, World Economic Outlook: 
Globalization, Opportunities and Challenges, Washington, D.C.: International Monetary Fund, 1997); J. Stiglitz, Globalization and its discontents (New York: Norton, 2002).

${ }^{19}$ OECD, Environmental Policy Stringency and Foreign Direct Investment, working paper (Paris: Working Party on Integrating Environmental and Economic Policies, Organisation for Economic Cooperation and Development, March 2011); B. Copeland and S. Taylor, "Trade, growth, and the environment," Journal of Economic Literature, 42/1 (2004): 7-71; D. Esty and D. Geradin, "Environmental protection and international competitiveness," Journal of World Trade, 32/3 (1998): 5-46.

20 A. Rugman and A. Verbeke, "Corporate strategies and environmental regulations: An organizing framework," Strategic Management Journal, 19 (1998): 363-375; A. Rugman and A. Verbeke, “Corporate strategy and international environmental policy," Journal of International Business Studies, 29/4 (1998): 819834.

${ }^{21}$ The work of Rugman and Verbeke (op. cit.) is an exception.

22 D. North, Institutions, Institutional Change and Economic Performance (Cambridge: Cambridge University Press, 1990); P. DiMaggio and W. Powell, "The iron cage revisited: Institutional isomorphism and collective rationality in organizational fields," American Sociological Review, 48/2 (1983): 147-160; R. Scott, Institutions and Organizations, $2^{\text {nd }}$ edn. (Thousand Oaks: Sage, 2001).

${ }^{23}$ D. Etzion, "Research on organizations and the natural environment, 1992-present: A review," Journal of Management, 33/4 (2007): 637-664; M. Delmas and O. Young (eds.), Governance for the Environment (Cambridge: Cambridge University Press, 2009).

${ }^{24}$ T. Tietenberg and L. Lewis, Environmental and Natural Resource Economics $\left(8^{\text {th }}\right.$ edition, Reading: Addison Wesley, 2008); W. Vermeend, R. van der Ploeg, and J.W. Timmer, Taxes and the Economy: A Survey on the Impact of Taxes on Growth, Employment, Investment, Consumption and the Environment (Cheltenham: Edward Elgar, 2008).

${ }^{25}$ G. Yip, Total Global Strategy: Managing for Worldwide Competitive Advantage (Englewood Cliffs: Prentice Hall, 1995); Bartlett and Ghoshal, op. cit.; Prahalad and Doz, op. cit.

26 H. Opschoor, "Globalisation, sustainable development, and environmental policies in developing countries," in F. Wijen et al. (eds.), op. cit.; Kaufmann et al., op. cit.

${ }^{27}$ The WEF's Executive Opinion Survey collected data among some 10,000 executives in over 100 countries on the stringency of different aspects of national environmental regulations. For details, see World Economic Forum, The Global Competitiveness Report (Oxford: Oxford University Press, 2008).

${ }^{28}$ Regulatory fluctuation is measured as the cumulative value of two variables for the period 2001-2008: the standard deviation of the average regulatory stringency and the degree of variance from one year to another.

${ }^{29}$ The two components of regulatory fluctuation (stringency differences and fluctuations) can either reinforce one another (e.g., when a relatively stringent regime further tightens up its regulation) or can balance out (e.g., when a relatively lax regime becomes stricter).

${ }^{30}$ OECD, op. cit.

${ }^{31}$ R. van Tulder, "The past, present and future of managing distance: Stakeholders and development," in T. Devinney, T. Pedersen, and L. Tihanyi (eds.), The Past, Present and Future of International Business \& Management (Bingley: Emerald, 2010).

${ }^{32}$ While regulatory stringency may be comparable, it may take different forms. For instance, Germany and the United Kingdom have similar degrees of stringency (see Table 1), but the former tends to rely on codified law while the latter privileges case law.

${ }^{33}$ H. Barkema and R. Drogendijk, "Internationalising in small, incremental or in larger steps," Journal of International Business Studies, 38/7 (2007): 1132-1148.

${ }^{34}$ P. Buckley, "The impact of the global factory on economic development," Journal of World Business, 44/2 (2009): 131-143.

${ }^{35}$ A. Lewin and C. Peeters, "Offshoring work: Business hype or the onset of fundamental transformation?," Long Range Planning, 39/3 (2006): 221-240.

${ }^{36}$ J. Barthélemy, "The hidden costs of IT outsourcing," MIT Sloan Management Review (42/3, 2001): 60-69.

${ }^{37}$ A. Slangen and R. van Tulder, "Cultural distance, political risk, or governance quality? Towards a more accurate conceptualization and measurement of external uncertainty in foreign entry mode research," International Business Review, 18/3 (2009): 276-291.

${ }^{38}$ T. Kostova and S. Zaheer, "Organizational legitimacy under conditions of complexity: The case of the multinational enterprise", Academy of Management Review (24/1, 1999): 64-81; R. van Tulder with A. Van der Zwart, International Business-Society Management: Linking Corporate Responsibility and Globalization (London: Routledge, 2006). 
${ }^{39}$ R. van Tulder with A. van der Zwart, op. cit.

40 The TNI is a fair but imperfect indicator, to the extent that MNEs may have a high degree of internationalization yet follow a multi-domestic strategy with limited market interdependence. Despite its limitation, we use the TNI as a proxy for market interdependence since it is the best available indicator to systematically compare (large) MNEs and because a higher degree of internationalization implies, by and large, a higher degree of market interconnectedness since MNEs need to draw on transferable firm-specific advantages (in terms of superior reputation, cost structure, etc.) to overcome their liability of foreignness (i.e., their competitive disadvantage vis-à-vis local firms who know local markets and institutions better).

${ }^{41}$ UNCTAD/Erasmus University, op. cit.: 18.

${ }^{42}$ Calculations based on UNCTAD/Erasmus University, op. cit. (Annexes Tables 26 and 27), corrected for double counts.

${ }^{43}$ The four strategies are the dominant strategies, which may be accompanied by supporting strategies (such as stakeholder engagement, lobbying, and spreading risks through geographic differentiation), which may be effective under any configuration.

${ }^{44}$ M. Lehrer and C. Delaunay, "Multinational enterprises and the promotion of civil society: The challenge for $21^{\text {st }}$ century capitalism," California Management Review, 51/4 (2009): 126-174.

45 J.A. Aragón-Correa and S. Sharma, "A contingent resource-based view of proactive corporate environmental strategy", Academy of Management Review, 28/1 (2003): 71-88; V. Hoffmann, T. Trautmann, and J. Hamprecht, "Regulatory uncertainty: A reason to postpone investments? Not necessarily," Journal of Management Studies, 46/7 (2009): 1227-1253.

${ }^{46}$ D. Wheeler, "Racing to the bottom? Foreign investment and air pollution in developing countries", Journal of Environment and Development, 10/3 (2001): 225-245.

${ }^{47}$ M. Lehrer and C. Delaunay, op. cit.; M. Valente and A. Crane, "Public responsibility and private enterprise in developing countries," California Management Review, 52/3 (2010): 52-78.

${ }^{48}$ A. Hoffman, "Climate change strategy: The business logic behind voluntary greenhouse gas reductions," California Management Review, 47/3 (2005): 21-46.

${ }^{49}$ E. von Weizsäcker, K. Harlgroves, M. Smith, C. Desha, and P. Stasinopoulos, Factor Five: Transforming the Global Economy through 80\% Improvements in Resource Productivity (London: Earthscan, 2009); H. Choi Granade et al., Unlocking Energy Efficiency in the US Economy (McKinsey Global Energy and Materials, July 2009); W. Prindle, From Shop Floor to Top Floor: Best Business Practices in Energy Efficiency (Pew Center on Global Climate Change, April 2010).

50 M. Porter and C. van der Linde, "Toward a new conception of the environment-competitiveness relationship", Journal of Economic Perspectives, 9/4 (1995): 97-118.

${ }^{51}$ A. Kolk and J. Pinkse, "Business responses to climate change: Identifying emergent strategies", California Management Review (47/3, 2005): 6-20; MIT Sloan Management Review/ Boston Consulting Group, "Sustainability: The 'embracers' seize advantage", Sloan Management Review (Winter 2011): 1-27.

${ }_{52}$ M. Tushman and E. Romanelli, "Organizational evolution: A metamorphosis model of convergence and reorientation," in L. Cummings and B. Staw (eds.), Research in Organizational Behavior (Greenwich: JAI Press, 1985); R. Nelson and S. Winter, An Evolutionary Theory of Economic Change (Cambridge: Harvard University Press, 1982); B. Nooteboom), Learning and Innovation in Organizations and Economies (Oxford: Oxford University Press, 2000).

${ }^{53}$ M. Benner and M. Tushman, "Process management and technological innovation: A longitudinal study of the photography and paint industries," Administrative Science Quarterly, (47, December 2002): 676-706.

${ }^{54}$ R. Orsato, "Competitive environmental strategies: When does it pay to be green?," California Management Review, 48/2 (2006): 127-143; A. Hoffman, op. cit.

${ }^{55}$ P. Vergragt and M. van der Wel, "Backcasting: an example of sustainable washing," in N. Roome (ed.), Sustainability Strategies for Industry; The Future of Corporate Practice (Washington, D.C.: Island Press, 1998).

${ }^{56}$ D. Esty and A. Winston, Green to Gold: How Smart Companies Use Environmental Strategy to Innovate, Create Value, and Build Competitive Advantage (Hoboken: Wiley, 2009); MIT Sloan Management Review/ Boston Consulting Group, op. cit.

57 IMD, Tata Nano: Dilemmas in Sustainable Development (Teaching case IMD-3-1947, 7 April 2010, Lausanne: IMD).

${ }^{58}$ J.S. Gabrielli de Azevedo, “The greening of Petrobras,” Harvard Business Review (March 2009).

${ }^{59}$ S. Rocchi and Y. Kusume, "Empowering creativity: A design-led innovation experience based on value cocreation and user insights," in P. Kandachar and M. Halme (eds.), Sustainability Challenges and Solutions at the Base of the Pyramid (Sheffield: Greenleaf, 2008). 
${ }^{60}$ T. Jones, "Trade and investment: Selected links to domestic environmental policy," in F. Wijen, K. Zoeteman, and J. Pieters (eds.), A Handbook of Globalisation and Environmental Policy: National Policy Interventions in a Global Arena (Cheltenham: Edward Elgar, 2005).

${ }^{61}$ R. Ramamurti and J. Singh (eds.), Emerging Multinationals in Emerging Markets, (Cambridge: Cambridge University Press, 2009).

${ }^{62}$ Y. Luo and R. Tung, "International expansion of emerging market enterprises: A springboard perspective," Journal of International Business Studies, 38/4 (2007): 481-498.

${ }^{63}$ Ramamurti and Singh, op. cit.

${ }^{64}$ J. Pieters, "Standards and the internationalisation of environmental practices and policies," in F. Wijen et al. (eds.), op. cit.

${ }^{65}$ B. Kogut and N. Kulatilaka, "Operating flexibility, global manufacturing, and the option value of a multinational network”, Organization Science, 40/1 (1994): 123-139; Bartlett and Ghoshal, op. cit.; Yip, op. cit.

${ }^{66}$ D. Vogel, Trading up: Consumer and environmental regulation in a global economy (Cambridge: Harvard University Press, 1995).

${ }^{67}$ D. Spar and L. La Mure, "The power of activism: Assessing the impact of NGOs on global business," California Management Review, 45/3 (2003): 78-101; D. Vogel, "Private global business regulation," Annual Review of Political Science, 11/1 (2008): 261-282; T. Lyon (ed.), Good Cop Bad Cop: Environmental NGOs and their Strategies toward Business (Washington, D.C.: RFF Press, 2010).

${ }^{68}$ J. Rivera, Business and Public Policy: Responses to Environmental and Social Protection Processes (Cambridge: Cambridge University Press, 2010).

${ }^{69}$ Greenbizz, "Dow Jones Sustainability index adds Morgan Stanley, cuts Shell," www.greenbizz.com (9 September 2010).

70 Vogel (2008), op. cit.; T. Bartley, "Institutional emergence in an era of globalization: The rise of transnational private regulation of labor and environmental conditions," American Journal of Sociology, 113/2 (2007): 297-351; B. Cashore, G. Auld, and D. Newsom, Governing through Markets: Forest Certification and the Emergence of Non-State Authority (New Haven: Yale University Press, 2004).

${ }^{71}$ C. Dutilh, "Unilever and sustainable development," in F. Wijen et al. (2005), op. cit.

72 These products are referred to as 'credence goods,' since customers cannot readily observe certain (product-related or process-related) characteristics and thus need to believe claims of their suppliers (see, for instance, A. King and M. Toffel, "Self-regulatory institutions for solving environmental problems: Perspectives and contributions from the management literature," in M. Delmas and O. Young (eds.), op. cit.

${ }^{73}$ P. Christmann and G. Taylor, "Globalization and the environment: Determinants of firm self-regulation in China," Journal of International Business Studies, 32/3 (2001): 439-458; P. Christmann, "Multinational companies and the natural environment: Determinants of global environmental policy standardization," Academy of Management Journal, 47/5 (2004): 747-760; A. Prakash and M. Potoski, The Voluntary Environmentalist: Green Clubs, ISO 14001, and Voluntary Environmental Agreements (Cambridge: Cambridge University Press, 2006).

${ }^{74}$ Vogel (2008), op. cit.

${ }^{75}$ Greenpeace, Guide to Greener Electronics, $16^{\text {th }}$ ed. (www.greenpeace.org, October 2010).

${ }^{76}$ Vogel (1995), op. cit.

${ }^{77}$ Kalamova and Johnstone, op. cit.

${ }^{78}$ Kaufmann et al., op. cit.

${ }^{79}$ Opschoor, op. cit.

${ }^{80}$ World Bank, The Cost of Pollution in China: Economic Estimates of Physical Damage (Washington, D.C.: World Bank, 2007).

${ }^{81}$ M. Cole and E. Neumayer, "Environmental policy and the environmental Kuznets curve: Can developing countries escape the detrimental consequences of economic growth?," in P. Dauvergne (ed.), Handbook of Global Environmental Politics (Cheltenham: Edward Elgar, 2005).

${ }^{82}$ UNCTAD/Erasmus University, op. cit.; Hoffman, op. cit.; McKinsey Global Energy and Materials, op. cit.; Prindle, op. cit.

83 I. Berger, P. Cunningham, and M. Drumwright, "Mainstreaming corporate social responsibility: Developing markets for virtue," California Management Review, 49/4 (2007): 132-157.

84 A. Marcus and A. Fremeth, "Green management matters regardless," Academy of Management Perspectives, 23/3 (2009): 17-26. 